\title{
LAND COVER AND LAND USE CHANGE-DRIVEN DYNAMICS OF SOIL ORGANIC CARBON IN NORTH-EAST SLOVAKIAN CROPLANDS AND GRASSLANDS BETWEEN 1970 AND 2013
}

\author{
RASTISLAV SKALSKÝ ${ }^{1,2^{*}}$, ŠTEFAN KOCO ${ }^{1,3}$, GABRIELA BARANČÍKOVÁ ${ }^{1,7}$, ZUZANA \\ TARASOVIČOVÁ ${ }^{1}$, JÁN HALAS ${ }^{1}$, PETER KOLEDA ${ }^{4}$, JARMILA MAKOVNÍKOVÁ ${ }^{1}$, \\ MONIKA GUTTEKOVÁ ${ }^{1}$, ERIKA TOBIÁŠOVÁ ${ }^{5}$, ERIKA GÖMÖRYOVÁ ${ }^{6}$, JOZEF TAKÁČ ${ }^{1}$
}

${ }^{1}$ Soil Science and Conservation Research Institute, National Agricultural and Food Centre, Trenčianska 55, 821 09 Bratislava, Slovak Republic; e-mail: rastislav.skalsky@nppc.sk, stefan.koco@nppc.sk, gabriela.barancikova@nppc. sk, z.tarasovicova@gmail.com, jarmila.makovnikova@nppc.sk, monika.guttekova@nppc.sk, jozef.takac@nppc.sk ${ }^{2}$ Ecosystems Services and Management Program, International Institute for Applied Systems Analysis, Schlossplatz 1, A-2361 Laxenburg, Austria; e-mail: skalsky@iiasa.ac.at

${ }^{3}$ Department of Geography and Applied Geoinformatics, Faculty of Humanities and Natural Sciences, University of Prešov, 17. novembra 1, 08116 Prešov, Slovak Republic

${ }^{4}$ National Forest Center, T. G. Masaryka 22, 96092 Zvolen, Slovak Republic; e-mail: koleda@nlcsk.org

${ }^{5}$ Department of Soil Science, Faculty of Agrobiology and Food Resources, Slovak University of Agriculture, Tr. A. Hlinku 2, 94976 Nitra, Slovak Republic; e-mail: erika.tobiasova@uniag.sk

${ }^{6}$ Department of Natural Environment, Faculty of Forestry, Technical University in Zvolen, T.G. Masaryka 24, 96053 Zvolen, Slovak Republic; e-mail: gomoryova@tuzvo.sk

${ }^{7}$ Department of Environmental Management, Faculty of Management, University of Prešov, Konštantínova 16, 080 01 Prešov, Slovak Republic; e-mail: gabriela.barancikova@unipo.sk

* Author for correspondence

Abstract

Skalský R., Koco Š., Barančíková G., Tarasovičová Z., Halas J., Koleda P., Makovníková J., Gutteková M., Tobiášová E., Gömöryová E., Takáč J.: Land cover and land use change-driven dynamics of soil organic carbon in North-East Slovakian croplands and grasslands between 1970 and 2013. Ekológia (Bratislava), Vol. 39, No. 2, p. 159-173, 2020.

Soil organic carbon (SOC) in agricultural land forms part of the global terrestrial carbon cycle and it affects atmospheric carbon dioxide balance. SOC is sensitive to local agricultural management practices that sum up into regional SOC storage dynamics. Understanding regional carbon emission and sequestration trends is, therefore, important in formulating and implementing climate change adaptation and mitigation policies. In this study, the estimation of SOC stock and regional storage dynamics in the Ondavská Vrchovina region (North-Eastern Slovakia) cropland and grassland topsoil between 1970 and 2013 was performed with the RothC model and gridded spatial data on weather, initial SOC stock and histori$\mathrm{cal}$ land cover and land use changes. Initial SOC stock in the $0.3-\mathrm{m}$ topsoil layer was estimated at $38.4 \mathrm{t}$ $\mathrm{ha}^{-1}$ in 1970. The 2013 simulated value was $49.2 \mathrm{t} \mathrm{ha}^{-1}$, and the 1993-2013 simulated SOC stock values were within the measured data range. The total SOC storage in the study area, cropland and grassland areas, was 4.21 Mt in 1970 and 5.16 Mt in 2013, and this 0.95 Mt net SOC gain was attributed to interconversions of cropland and grassland areas between 1970 and 2013, which caused different organic carbon inputs to the soil during the simulation period with a strong effect on SOC stock temporal dynamics.

Key words: soil organic carbon stock, regional soil organic carbon storage, soil organic carbon modelling, RothC, legacy soil data. 


\section{Introduction}

Soil organic carbon (SOC) is one of the most important soil constituents, and it affects many soil and ecosystem processes. These include soil physical structure, its fertility and water-holding capacity (Vopravil et al., 2014; Campbell, Paustian, 2015). Moreover, Banwart et al. (2015) considered that SOC has a key role in all soil ecosystem services because not only it is sensitive to climate change, as recorded by Smith et al. (2005), but also it has both direct and indirect impacts from agricultural management practices (Janzen, 2006) and land use changes (Minasny et al., 2014; Vopravil et al., 2014).

The direction of SOC quantity and quality changes in the most anthropogenic affected ecosystems is controlled by their historical and actual use, and it is estimated that soil cultivation, and especially conversion of grassland to croplands, leads to significant SOC losses. In the overall global balance, Janzen (2006) confirmed that this can be as high as 50Pg carbon emitted because of land conversion and Guo and Gifford's (2002) meta-analysis estimated that SOC stock loss in converting grassland to cropland is up to $59 \%$.

Crop and soil management are additional important factors influencing SOC stock in agricultural areas because these are intimately connected with particular land use. The low input of organic carbon from crop residues and insufficient supply of high-quality organic fertilisers can increase SOC mineralisation and decrease its overall stock in intensively managed croplands (Capriel, 2013). Conversely, many agricultural practices can offset the negative impacts of intensive cultivation and provide opportunity for long-term sequestration of organic carbon in intensively used cropland soils (Janzen, 2006; Lehtinen, 2014; Barančíková et al., 2014). These include the application of manure or compost, optimal crop rotation, minimum soil tillage or a lack of till technology, proper water management and soil protection technology, which includes mixing crop residues with soil and the subsequent application of organic fertilisers.

The combination of on-site effects of local management strategies and farmers' decisions on topsoil SOC dynamics translates into regional SOC storage dynamics, and understanding SOC dynamics on the larger regional, national and global scales is the most important in estimating the carbon emission and sequestration trends associated with agricultural practices (Smith et al., 2005). This knowledge focuses on SOC management, and it provides possible input for evaluating existing policies and formulating new ones that adapt to climate change and mitigate its impacts with agricultural practices (Frank et al., 2015).

Although information on the large-scale SOC stock temporal dynamics driven by land cover land use changes is limited by available data with appropriate spatial and temporal resolution, the process-based models combined with spatially explicit quantitative data on topsoil SOC, weather and land use prove effective in overcoming this problem (as in Barančíková et al., 2010; Alvaro-Fuentes et al., 2011; Gottshalk et al., 2012; Barančíková et al., 2012; Ma et al., 2016; Kaczynski et al., 2017).

For this purpose, the RothC turnover model (Coleman, Jenkinson, 2014) is most commonly used in SOC management studies because it can be run on single-site basis or integrated with geographical data sets to provide spatially explicit estimates for regions, countries and the world (Falloon, Smith, 2012; Campbell, Paustian, 2015; Gottshalk et al., 2012; Wang et al., 2016; van Wesemael et al., 2010; Barančíková et al., 2013). 
This model was successfully used in reconstructing the 1970-2010 Slovak crop and grasslands topsoil SOC stock development trajectory and also for estimating the current SOC levels on a national scale (Barančíková et al., 2010, 2012, 2013). However, these authors record that the results provide only approximate SOC stock estimates because of limitations in the spatial resolution of gridded data $(10 \times 10 \mathrm{~km})$ on organic carbon inputs from management, the monthly weather records and the initial 1970's SOC stock estimated from the soil map and profile data from the Slovak National agricultural soils inventory used to run the RothC model. This research also neglects marginal cropland and grassland areas and does not consider land cover change during the simulation period (Barančíková et al., 2012, 2013).

This study focuses on the Ondavská Vrchovina highland region located in the West Carpathian mountain range in North-East Slovakia. The study region has experienced significant land cover and land use changes over the past 50 years, including conversions of grasslands and croplands; and it is, therefore, a good example of these changes in Slovak sub-mountain and inner-mountain basin areas. Here, we used the RothC model to estimate the 1970-2013 SOC stock and regional SOC storage dynamics in cropland and grassland in Ondavská Vrchovina region between 1970 and 2013 as affected by cropland and grassland conversions and associated crop management.

\section{Materials and methods}

\section{Study area}

The 3,129 $\mathrm{km}^{2}$ Ondavská Vrchovina highlands form part of the West Carpathian Mountains in North-eastern Slovakia (Fig. 1). The study area altitude ranges from $114 \mathrm{~m}$ in the southernmost part to $1,090 \mathrm{~m}$ in the north, with a

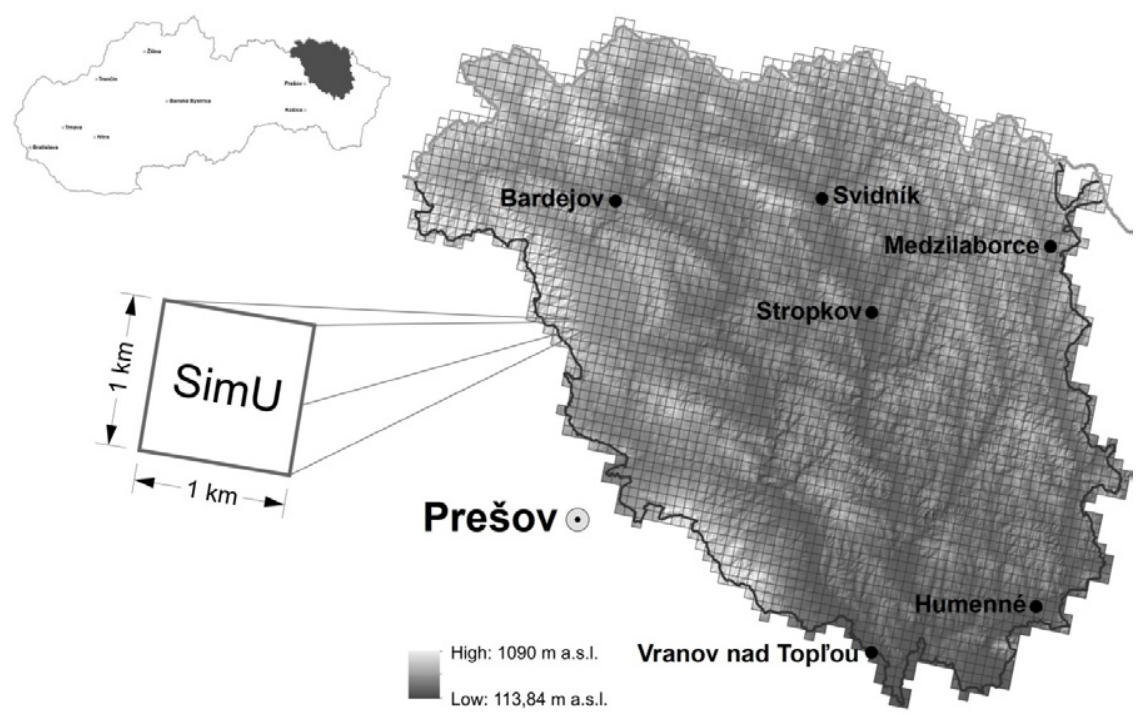

Fig. 1. Location and topography of Ondavská Vrchovina highland region, and spatial simulation units (SimU) for running RothC model. 
mean of $360 \mathrm{~m}$. The mean annual temperature ranges from 7 to $8^{\circ} \mathrm{C}$. July is the warmest with $22.8-23.8^{\circ} \mathrm{C}$, January is the coldest with -3.6 to $4.3{ }^{\circ} \mathrm{C}$, and the annual rainfall ranges from $600-650 \mathrm{~mm}$ in lower regions to $650-700$ $\mathrm{mm}$ in higher mountain areas. Dystric and Eutric Cambisols developed from tertiary sedimentary sandstones and siltstones dominate the mountain positions, whereas the lower mountain foot has gently sloping topography with Stagnic Cambisols, Stagnic Luvisols and Stagnosols from quaternary unconsolidated slope sediments. Fluvisols are then located in the floodplains. The texture of soils is mostly medium, locally coarse or fine. Stone content is higher in Cambisols and lower or absent in Luvisols and Stagnosols. The study area comprises broadleaf and mixed forests in the higher mountains areas and grass and cropland at lower elevations.

\section{RothC model}

The Rothc-26.3 model (Coleman, Jenkinson, 2014) determines the turnover of organic carbon in non-waterlogged soils. The SOC turnover process is affected by weather, plant cover, soil type and organic carbon input. The model used a monthly time step to calculate carbon turnover in the soil, and it can operate on annual to century time scales. The model splits total SOC pool into four active compartments (decomposable plant material, resistant plant material, microbial biomass and hummified organic matter) and a small amount of inert organic matter.

The model requires data on weather (monthly rainfall [mm], monthly open-pan evaporation [mm], average monthly mean air temperature $\left[{ }^{\circ} \mathrm{C}\right]$ ), soil (clay content [\%], content of inert organic carbon [IOM, \%], soil-layer depth [cm]), land use and management (soil cover presence, monthly input of plant residues $\left[\mathrm{t} \mathrm{C} \mathrm{ha}^{-1}\right]$ and the monthly input of farmyard manure $\left.\left[\mathrm{t} \mathrm{Cha}^{-1}\right]\right)$.

\section{Weather data}

This was obtained from three WMO (World Meteorological Organization) international meteorological stations located directly in the study area (WMO 11976 - Stropkov-Tisinec and WMO 11977 - Medzilaborce) or close to it (WMO 11993 Kamenica nad Cirochou). Daily temperature records $\left({ }^{\circ} \mathrm{C}\right)$ and sum of rainfall $(\mathrm{mm})$ for each year of the simulation period (1970-2013) were then aggregated to the monthly mean values. This was complemented by daily potential evapotranspiration [mm] estimated using the Penman-Monteith method and summated to monthly values to replace the open-pan evaporation data required by the RothC model.

\section{Land cover and land use data}

There is no consistent study area land cover product available for the entire 1970-2013 period, so multiple data resources were used to reconstruct land cover dynamics. Polygon data from the national Land Parcel Identification System (LPIS) was the basic source used to identify agricultural parcel borders and cropland and grassland areas in 2003 and 2013.

The Landsat 4, 5 and 7 imageries at 30-m spatial resolution were interpreted in LPIS agricultural area borders, and this yielded crop and grassland area estimates for 1986 and 1994. Content from the 1965 military topography maps in 1:10,000 scale was digitised, and the interpreted map legend provided initial $1970 \mathrm{crop}$ and grassland areas.

Historical land use data for Slovakia are mostly limited to national agricultural statistics for harvested crop areas, crop yields and the number of animals and their manure products at national, regional (NUTS3) and district (NUTS4) levels. District-level statistics on harvested crop areas were used to reconstruct annual crop shares for the period before 2003. LPIS data and farmer's declarations for each registered agricultural parcel provided the first official crop area information after 2003. The annual district-level statistics on crop yields, the annual crop share data and national carbon conversion coefficients recommended for SOC balanced crop production in Slovakia by Bielek and Jurčová (2010) enabled organic carbon inputs calculation from plant residues $\left[\mathrm{t} \mathrm{C} \mathrm{ha}^{-1}\right]$ separately for the cropland and grassland areas. The annual farmyard manure inputs were calculated from the district-level statistics on farmyard manure application rates and the number of animals per unit area. More precise estimates of animal distribution were possible after 2003 from the National Veterinary GIS farm-level data on animal number and type. Cropland- and grassland-specific organic carbon inputs from farmyard manure $\left[\mathrm{t} \mathrm{C} \mathrm{ha}^{-1}\right]$ were then estimated using the carbon conversion coefficients by Bielek and Jurčová (2010).

\section{Initial SOC stock}

The dominant soil typological unit of soil type, soil texture class and stone content was assigned to each agricultural parcel for both cropland and grassland from 1:10,000 polygon soil maps (Němeček et al., 1967; Hraško, Bedrna, 1970), and 
topsoil SOC concentrations [\%] were allocated from the closest measured soil profile (Linkeš et al., 1988) for the same soil typological unit and land cover class (Table 1).

T a b l e 1. Topsoil (0-30 cm) SOC concentration [\%] in pre-stratified measured soil profiles used as an input for calculating initial topsoil SOC stock for the pilot area.

\begin{tabular}{|l|c|c|c|c|c|c|c|c|}
\hline \multirow{2}{*}{$\begin{array}{l}\text { Soil/land } \\
\text { cover class }\end{array}$} & Min & Max & Mean & $\begin{array}{c}\text { Standard } \\
\text { devia- } \\
\text { tion }\end{array}$ & Median & Lower & Upper & \multirow{2}{*}{$\begin{array}{c}\text { Quartile } \\
\text { count }\end{array}$} \\
\hline HM & 0.45 & 1.73 & 0.85 & 0.21 & 0.84 & 0.71 & 0.96 & 222 \\
\hline RA & 0.48 & 1.95 & 0.99 & 0.35 & 0.91 & 0.74 & 1.18 & 62 \\
\hline KM_C & 0.40 & 3.47 & 1.02 & 0.36 & 0.94 & 0.76 & 1.19 & 554 \\
\hline KM_G & 0.43 & 3.02 & 1.12 & 0.47 & 1.03 & 0.79 & 1.30 & 209 \\
\hline FM_C & 0.44 & 3.05 & 1.22 & 0.44 & 1.15 & 0.94 & 1.42 & 159 \\
\hline FM_G & 0.48 & 3.06 & 1.39 & 0.50 & 1.32 & 1.02 & 1.66 & 84 \\
\hline CA_C & 0.71 & 2.59 & 1.44 & 0.44 & 1.35 & 1.20 & 1.68 & 18 \\
\hline
\end{tabular}

Notes: HM - Albic/Stagnic Luvisols; RA - Rendzic Phaeozem; CA_C - Endogleyic Phaeozem/Mollic Fluvisol on cropland; KM_C - Cambisols on cropland; KM_G - Cambisols on grassland; FM_C - Fluvisols on cropland; FM_G - Fluvisols on grassland.

The topsoil clay content for each agricultural parcel was calculated as the weighted mean from the 20-m spatial resolution raster of topsoil clay content previously derived from measured soil profile data (Balkovič et al., 2010). The stone content was then taken directly from the soil map. However, the bulk density values $\left(\mathrm{t} \mathrm{ha}^{-1}\right)$ equired for SOC stock calculation were not available in the original data, and these had to be estimated by regional pedotransfer function for Slovakia (Makovníková, Širáň, 2011):

$$
B D_{i j}=1.52644+0.0000517149 * C L A Y_{i j}-0.107002 * C O X_{i j}
$$

where $B D$ is the soil bulk density $\left(\mathrm{g} \mathrm{cm}^{-3}\right)$, CLAY is the topsoil clay content (\%), COX is the topsoil SOC concentration (\%), $i$ is the $i$-th agricultural parcel and $j$ is either cropland or grassland. The SOC stock for each parcel was then calculated as

$$
S O C_{i j}=\left(B D_{i j} * C O X_{i j} *\left(30 *\left(1-\frac{S C_{i j}}{100}\right)\right)\right.
$$

where SOC is the SOC stock in $0-30 \mathrm{~cm}$ depth $\left(\mathrm{t} \mathrm{ha}^{-1}\right), B D$ is the soil bulk density $\left(\mathrm{g} \mathrm{cm}^{-3}\right), C O X$ is the topsoil SOC concentration (\%), SC is the topsoil stone content (\%), $i$ is the $\mathrm{i}$-th agricultural parcel and $j$ is either cropland or grassland.

All estimated SOC stock values were relevant for 1970; and the area-weighted mean was calculated from data on the individual parcels to provide initial SOC stock values for cropland and grassland areas within the $1 \times 1 \mathrm{~km}$ spatial resolution grid cells (Fig. 1).

The RothC model requires initial SOC stock to be pooled in five compartments before SOC balance is calculated. Therefore, simulations with in-built model equilibrium mode were performed to obtain the SOC content in the different compartments, and the model was run by applying pedotransfer estimation (Falloon et al., 1998) of inert SOC compartment values necessary to run the model:

$$
I O M=0.049 * S O C j^{1.139}
$$

where $I O M$ is the inert organic carbon $\left(\mathrm{t} \mathrm{ha}^{-1}\right), S O C$ is the initial SOC stock ( $\left.\mathrm{t} \mathrm{ha}^{-1}\right)$ estimated for 1970 and $j$ is either cropland or grassland. 
In addition to compartmental SOC content, the RothC model also provides balanced organic carbon input values to the soil, which can keep initial SOC stock values unchanged in constant climate over thousands of years. These inputs arise as outputs from the model equilibrium runs.

\section{Model setup and SOC stock simulations}

Simulation units (SimU) for running the RothC model were derived from individual cells of the $1 \mathrm{x} 1 \mathrm{~km}$ spatial resolution grid for the entire study area (Fig. 1). These SimU provided geographical reference for inputs and outputs of the RothC model and grassland and cropland areas (ha) for 1970, 1986, 1994, 2003 and 2013; and the inputs included monthly weather and land-cover-specific initial SOC stock, organic carbon input.

The precise timing of individual land conversion events in the pilot area between 1970 and 2013 was assumed to be unknown, and therefore, a set of theoretical scenarios on cropland to grassland and/or grassland to cropland conversions was prepared for each SimU to obtain theoretically possible SOC stock change trajectories. The scenarios were set to provide for both land cover change occurring at approximately 10-year intervals, thus corresponding to available land cover data from the pilot area and also instances of no assumed land conversion (Table 2).

The SOC stock dynamics for each SimU and theoretical land cover change scenario in Table 2 were simulated between 1970 and 2013 with either (1) annual organic carbon inputs from plant residues and farmyard manure reconstructed for the corresponding simulation period or (2) balanced organic carbon inputs to the soil from the equilibrium RothC runs. These balanced inputs provided reference SOC stock estimates without assuming impacts from land use.

Land-cover-specific SOC stock $\left(\mathrm{t} \mathrm{ha}^{-1}\right)$ for each SimU and each year was calculated as the weighted average using the SimU scenario area as the weight. Table 2 highlights that the land cover class was assigned with an estimated area for each scenario and year within the SimU based on land cover data available for the corresponding time period. This enabled total SOC storage (Mt) to be summated from SimU and land-cover-specific SOC storage (t) calculated annually from SOC stock multiplied by the cropland or grassland area in a given year.

$\mathrm{T}$ a b l e 2. Theoretical scenarios of cropland to grassland and grassland to cropland conversions within the individual SimU and land cover class which the scenario represents in the respective time intervals.

\begin{tabular}{|l|c|c|c|c|c|c|}
\hline Land cover conversion & \multicolumn{5}{|c|}{ Land cover class } \\
\hline Type & Occurred in & $\mathbf{1 9 7 0}$ & $\mathbf{1 9 7 1 - 1 9 8 0}$ & $\mathbf{1 9 8 0 - 1 9 9 0}$ & $\mathbf{1 9 9 0 - 2 0 0 0}$ & $\mathbf{2 0 0 0 - 2 0 1 3}$ \\
\hline C (no change) & - & C & C & C & C & C \\
\hline C to G & 1971 & C & G & G & G & G \\
\hline C to G & 1980 & C & C & G & G & G \\
\hline C to G & 1990 & C & C & C & G & G \\
\hline C to G & 2000 & C & C & C & C & G \\
\hline G (no change) & - & G & G & G & G & G \\
\hline G to C & 1971 & G & C & C & C & C \\
\hline G to C & 1980 & G & G & C & C & C \\
\hline G to C & 1990 & G & G & G & C & C \\
\hline G to C & 2000 & G & G & G & G & C \\
\hline
\end{tabular}

Notes: C - cropland; G - grassland.

\section{Results}

\section{Historical development of land cover and land use}

The agricultural area in the Ondavská Vrchovina highland region in 2013 was $34 \%$ of the total area $(107,506 \mathrm{ha})$. This area was assumed as constant throughout the simulation period, and 


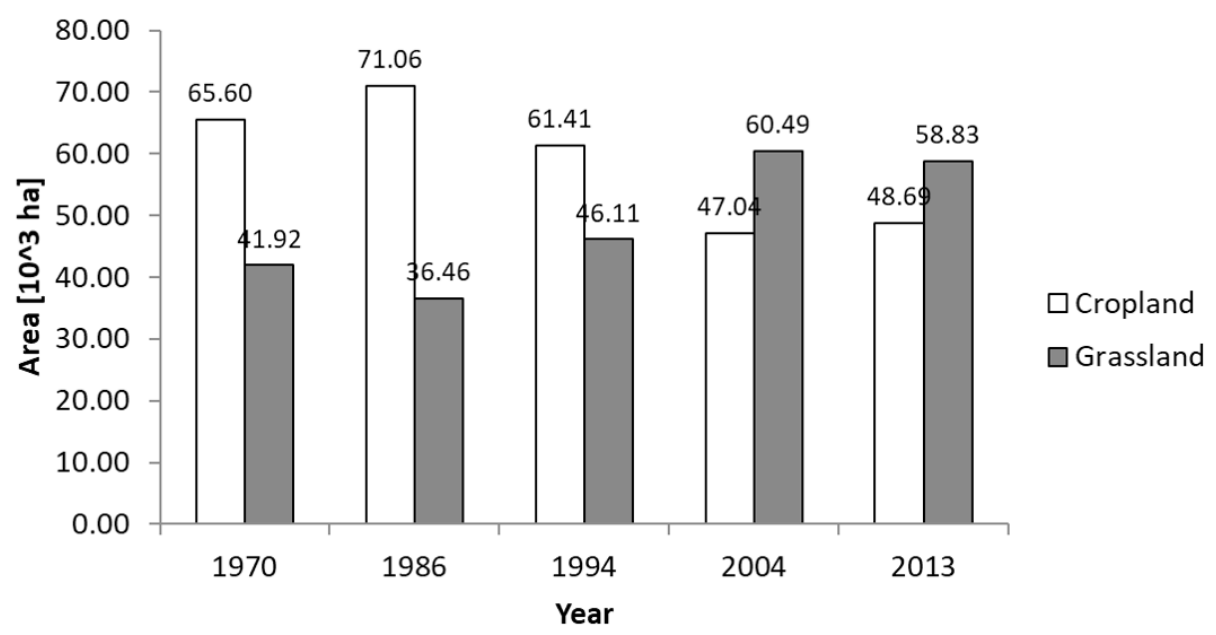

Fig. 2. Historical development of cropland and grassland areas in the Ondavská Vrchovina highland region between 1970 and 2013.

therefore, only the impact of cropland and grassland conversions on total SOC storage was estimated. The combination of cropland and grassland, which was 61 and 39\%, respectively, in 1970, underwent maximum change in 1986 to 66 and 34\%, respectively. The cropland percentage then decreased continuously to $57 \%$ of the total area by 1994 , to a minimum of $44 \%$ in 2003 and slightly increased to $45 \%$ by 2013 (Fig. 2); grasslands correspondingly increased to 43,56 and $55 \%$ at these times.

Table 3 lists the average organic carbon inputs from plant residue and farmyard manure estimated from existing data from the Ondavská Vrchovina highland region between 1970 and 2013. Average inputs, however, varied between the cropland and grassland.

The average organic carbon input to cropland was approximately $2.3 \mathrm{t} \mathrm{C} \mathrm{ha}{ }^{-1}$, with farmyard manure supplying $24 \%$ of this amount. This remained balanced between 1970 and 2000,

T a b l e 3. Input of plant residua and farmyard manure as estimated for the Ondavská Vrchovina highland region between 1970 and 2013 .

\begin{tabular}{|l|c|c|c|c|c|c|}
\hline \multirow{2}{*}{ Decade } & \multicolumn{3}{|c|}{ Cropland $\left(\mathbf{t ~ C ~ h a ~}^{-1} \mathbf{y r}^{-1}\right)$} & \multicolumn{3}{c|}{ Grassland (t C ha $\left.\mathbf{y r}^{-1}\right)$} \\
\cline { 2 - 7 } & C_PR & C_FYM & C_PR+ C_FYM & C_PR & C_FYM & C_PR+ C_FYM \\
\hline $1970-1980$ & 1.74 & 0.54 & 2.28 & 2.88 & 1.07 & 3.95 \\
\hline $1981-1990$ & 1.64 & 0.54 & 2.18 & 2.88 & 1.17 & 4.05 \\
\hline $1991-2000$ & 1.75 & 0.53 & 2.28 & 2.09 & 0.66 & 2.75 \\
\hline $2001-2013$ & 2.62 & 0.57 & 3.19 & 1.77 & 1.07 & 2.84 \\
\hline
\end{tabular}

Notes: C_PR - organic carbon from plant residua; C_FYM - organic carbon from farmyard manure. 
but whilst the average organic carbon input increased by approximately one-third between 2001 and 2013, the farmyard manure portion decreased to $18 \%$.

Meanwhile, the average amount of organic carbon input to the grassland was approximately $4 \mathrm{t} \mathrm{C} \mathrm{ha}{ }^{-1}$ between 1970 and 1990, and farmyard manure was approximately $28 \%$ of this amount. The average organic carbon input then decreased from 1990 to 2013 to approximately $2.8 \mathrm{t} \mathrm{C} \mathrm{ha}^{-1}$, but the plant residue to farmyard manure ratio remained balanced, with the farmyard manure carbon input at $31 \%$.

\section{Initial SOC stock and its temporal dynamics between 1970-2013}

The average initial 0- to 30-cm topsoil SOC stock in the Ondavská Vrchovina region was 38.4 $\mathrm{t} \mathrm{ha}^{-1}$ in 1970, with $38.4 \mathrm{t} \mathrm{ha}^{-1}$ for croplands and $39.0 \mathrm{t} \mathrm{ha}^{-1}$ for grasslands. This initial value was $30 \%$ lower than the national average of $54.7 \mathrm{t} \mathrm{ha}^{-1}$ around 1970 (Barančíková et al., 2010); and it was mainly due to low $1 \%$ average topsoil SOC concentrations in the areas' dominant Cambisol and Luvisol soil types, with even lower values for Luvisols (Table 2).

The average SOC stock in agricultural land estimated for 2013 was $49.2 \mathrm{t} \mathrm{ha}^{-1}$. Figure 3 highlights that this was $28 \%$ higher than the initial 1970 stock and it continually increased over the entire simulation period, except for a minor decrease around 2000.

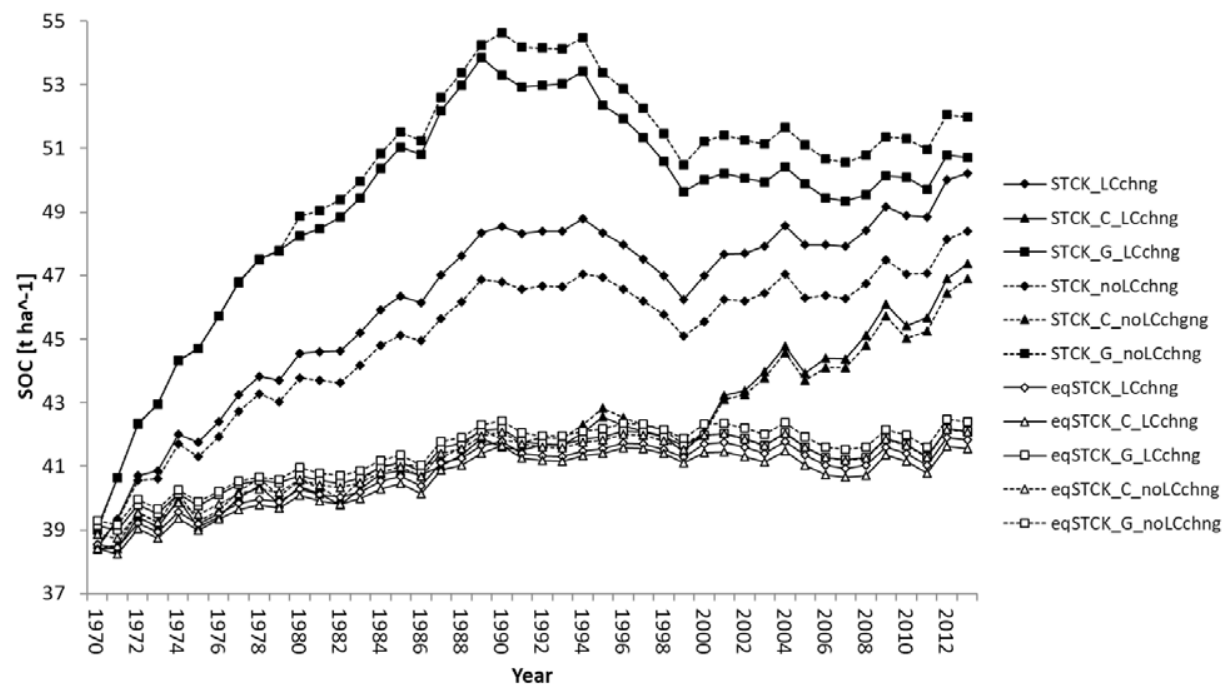

Fig. 3. Temporal development of SOC stock in Ondavská Vrchovina highland region between 1970 and 2013 under two different organic carbon inputs levels and with and without assuming land cover change in SOC simulations. Notes: STCK, SOC stock ( $\mathrm{ha}^{-1}$ ) as averaged across cropland and grassland areas together; STCKC, SOC stock (t $\left.\mathrm{ha}^{-1}\right)$ as averaged across cropland only; STCKG, SOC stock $\left(\mathrm{t} \mathrm{ha}^{-1}\right)$ as averaged across grassland only; LCchng, land cover change assumed; noLCchng, no land cover change assumed; eq, simulations with the organic carbon inputs at equilibrium. 
The cropland SOC stock continuously grew between 1970 and 2013 with more intensive topsoil SOC accumulation simulated in the final period of 2003-2013. Its 2013 average of $47.4 \mathrm{t} \mathrm{ha}^{-1}$ SOC was $23 \%$ higher than that at the beginning of the simulation period. Meanwhile, the grasslands SOC stock increased in the initial period of 1970-1986, culminating in $54.0 \mathrm{t} \mathrm{ha}^{-1}$ SOC in 1990. It then decreased rapidly to the 1986 level by 2003, and this value remained balanced over the next 10 years, so that the final $201349.4 \mathrm{t} \mathrm{ha}^{-1}$ SOC averaged $27 \%$ more than initial SOC stock.

\section{Land cover and land use change impact on SOC stock}

The impact of land cover change on SOC stock dynamics was analysed on the assumption that initial 1970 cropland and grassland areas remained constant over the entire simulation period and no land cover change occurred between 1970 and 2013 (Fig. 3).

However, whilst grasslands SOC stock values without land cover change were slightly higher than those with change over this period, the situation was different in croplands. There, the SOC stock values without land cover change were slightly higher before 2000 and then slightly lower than SOC stock estimated with land cover change (Fig. 3).

The difference in grassland SOC stock values in scenarios with and without land cover change is attributed to cropland to grassland conversions, mostly after 1990 when cropland areas with lower SOC stock commenced vast change to grasslands (Fig. 2). This was generally amplified in all agricultural land, where larger cropland areas negatively affected average SOC stock throughout the entire simulation period, with an average of $2.5 \%$ less than the SOC stock estimated with land cover change (Fig. 3).

The combined impact of amount and type of organic carbon inputs on SOC stock dynamics was analysed by comparing the simulation results from reconstructed annual organic carbon inputs with those plant residues established in the RothC equilibrium runs (Fig. 3, Table 3). The latter results provide organic carbon input, which is well balanced with initial SOC stock, and this can maintain unchanged SOC stock for long periods under constant climate conditions. It was estimated at $2.23 \mathrm{t} \mathrm{C} \mathrm{ha}^{-1} \mathrm{yr}^{-1}$ and included no farmyard manure.

Meanwhile, the combined croplands and grasslands average SOC stock relative to initial difference between the two was $14 \%$. The maximum of $22 \%$ was reached around 1990, and the results with plant residue at equilibrium were lower in both instances (Fig. 3, Table 4).

T a b l e 4. Relative to initial [\%] differences in SOC stock $\left(\mathrm{t} \mathrm{ha}^{-1}\right)$ during the simulation period (1970-2013) between the simulations with reconstructed organic carbon inputs $\left(\mathrm{t} \mathrm{C} \mathrm{ha}^{-1} \mathrm{yr}^{-1}\right)$ from Table 3 and balanced organic carbon input at equilibrium (2.23 $\mathrm{tC} \mathrm{ha}^{-1} \mathrm{yr}^{-1}$ for both the cropland and grassland).

\begin{tabular}{|l|c|c|c|}
\hline & Cropland + Grassland & Cropland & Grassland \\
\hline Mean & 14.2 & 3.6 & 20.8 \\
\hline Median & 15.4 & 1.4 & 0.0 \\
\hline Minimum & 0.0 & 0.0 & 20.0 \\
\hline Lower quartile & 11.5 & 0.8 & 25.2 \\
\hline Upper quartile & 17.9 & 5.9 & 30.0 \\
\hline Maximum & 21.8 & 15.2 & \\
\hline
\end{tabular}


The average difference between the two in grasslands was even higher, averaging $20.8 \%$ and culminating $30 \%$ by 1990 . Table 3 highlights that the reconstructed historical amount of organic carbon inputs to cropland was very low before 2000 , with only the $2.25 \mathrm{t} \mathrm{C} \mathrm{ha}^{-1} \mathrm{yr}^{-1}$ on an average, with almost negligible difference between the two carbon input scenarios. This increased by almost one-third after 2000 with the greatest difference in 2013 when the SOC stock under organic carbon input at equilibrium was $15.2 \%$ lower (Fig. 3, Table 3).

\section{Regional SOC storage between 1970 and 2013}

The initial 1970 regional 0- to 30-cm topsoil SOC storage in the Ondavská Vrchovina highland region for cropland, grassland and combined cropland and grassland was estimated at 2.57, 1.64 and 4.21 Mt, respectively (Fig. 4). However, by 2013, these amounts altered to 2.34 Mt (9\% decrease), 2.67 Mt (63\% increase) and 5.16 Mt (22.5\% increase). Thus, the croplands and grasslands regional SOC storage ratio was reversed over the simulation period, with cropland to grassland ratios of 62.4 to $37.5 \%$ in 1970 and 46.0 to $54.0 \%$ in 2013 . This is attributed to the historical development of cropland and grassland areas in this period (Fig. 2).

An analysis also highlights land cover conversions in the study period. There was $25.83 \%$ decrease in cropland area and $40.65 \%$ increase in grasslands, and $8.9 \%$ net cropland SOC storage decrease and $74.4 \%$ increase in the grasslands. This establishes that land cover change was not solely responsible for SOC storage dynamics. Moreover, Figure 4 shows that the assumption of no land cover change caused only marginal difference in the estimated total SOC storage in the study region from 5.16 to $5.18 \mathrm{Mt}$, but the individual trajectories for crop-

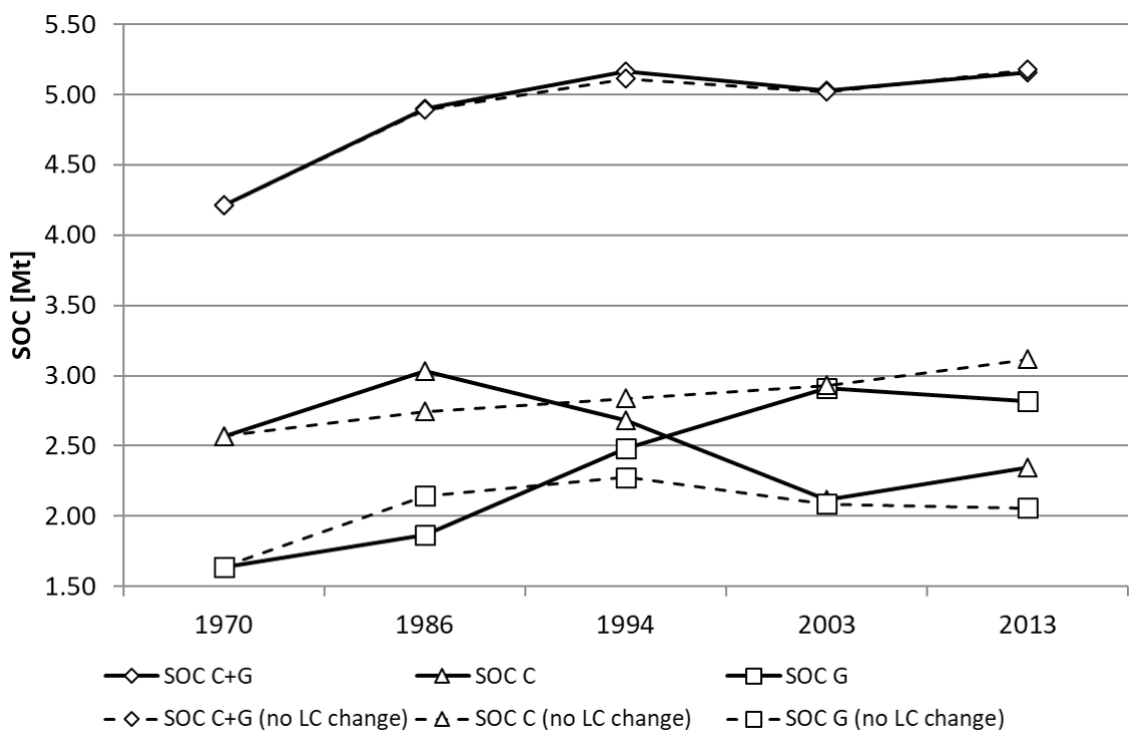

Fig. 4. Development of integral SOC stock (Mt) during the period 1970-2013 with and without conversions between cropland and grassland assumed (LC, land cover; C, cropland; G, grassland). 
land and grassland were different. These clearly exemplify the organic carbon inputs to the soil (Table 3), providing 21.4 and $25.5 \%$ increase in initial regional SOC storage in croplands and grasslands, respectively.

Although croplands continuously decreased in area, their organic carbon input continued to grow, thus buffering SOC losses. In contrast, the adverse effects of decreased management intensity after 1994 induced less grassland topsoil SOC accumulation than it would be expected by its increased area.

\section{Discussion}

\section{Reliability of the RothC model outputs for the study area}

The RothC model has responded appropriately to soil management in long-term experiments in Central and Western European conditions and determined realistic estimates (Ludwig et al., 2007; Leifeld et al., 2009). We, therefore, investigated if this held true for the Ondavská Vrchovina highland region by comparing the simulated values for cropland, grassland and combined cropland and grassland with the time series of measured topsoil SOC data from 11 permanent soil monitoring sites in the region (Bielek et al., 2005; Kobza, 2015).

Figure 5 depicts that the 1993 measured mean SOC stock was lower than the simulated average values but simulated values were still within the range of observations. An agreement between measured and simulated SOC stock improved towards the end of the simulation period, with simulated SOC stock values in the upper measured quartile. The SOC accumulation between 1970 and 2007 in Slovakia was also simulated at the national scale and validated with measured SOC data by Barančíková et al. (2010).

The 1971-2013 topsoil SOC stock increase under business-as-usual management of soils with low and medium 25-50 t ha ${ }^{-1}$ SOC

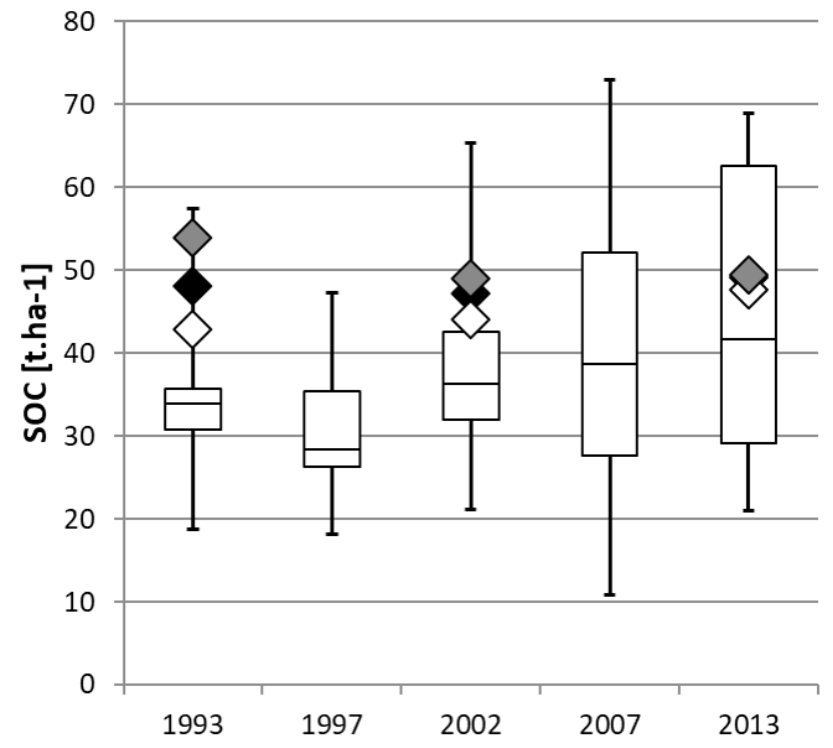

Fig. 5. Mean SOC stock ( $\left.\mathrm{t} \mathrm{ha}^{-1}\right)$ in cropland, grassland and cropland and grassland together plotted against the measured SOC data from the Ondavská Vrchovina highland region.

Notes: Boxes, median; upper and lower quartile, whiskers,10/90th percentile of measured data; diamonds, arithmetic mean of simulated values for cropland (white), grassland (grey), and cropland and grassland together (black). 
content was also simulated for similar climate conditions in southwest Poland (Kaczynski et al., 2017). In contrast, Smith et al. (2005) simulated a slightly decreasing trend in 1990-2010 in average crop and grassland topsoil SOC stock under an unchanged European management regime.

\section{Drivers of land cover and land use change}

The observed temporal dynamics of cropland and grassland areas in the Ondavská Vrchovina region (Fig. 2) are attributed to political and socio-economic changes in Slovak in 1970-2013. These comprised collectivisation and intensification of agricultural production between 1970 and 1990 followed by the sudden decrease in agricultural production after 1990 because of abandoned cropland and less animal husbandry. There was then a slight increase in the production intensity when Slovakia joined the European Union in 2004 (Blažík et al., 2011; Tarasovičová et al., 2013; Skokanová et al., 2016). Similar decreasing trend in agricultural area development was also observed by Masný et al. (2017) in mountain region of Central Slovakia between 1949 and 2006 occurring mostly at terrain positions less favourable for agricultural production. Significant conversions of small-parcel cropland to grassland because of collectivisation after 1970 were also recorded in other sub-mountain regions of Slovakia (Fazekašová et al., 2013; Mojses, Petrovič, 2013). The increasing trend of organic carbon inputs to the cropland in the study area after 1990 is attributed to higher production levels of the most important crops. This was promoted by the 1980's shift from fodder and potato production to biomass-rich technical crops; especially the rapeseed increase in North-eastern Slovakia after 2000 (Tarasovičová et al., 2013).

\section{SOC dynamics in response to land use change}

Agricultural soil SOC content is mainly influenced by organic carbon input from plant residue and manure (Schulp, Verbung, 2009; van Wesemael et al., 2010; Wang et al., 2013; Wang et al., 2016), and close correlation between 1970-2007 topsoil SOC content and organic carbon input was also identified in the study by Barančíkova et al. (2013).

In 1970-1990, the Ondavská Vrchovina highland region grasslands received substantially higher organic carbon from plant residue and farmyard manure than croplands (Table 3), and this is reflected in the SOC stock development trajectories for both areas before 1994 (Fig. 3). Grassland organic carbon inputs then suddenly decreased in response to 1990 political and socio-economical changes inducing less grazing animals and lower grassland management intensity (Blažík et al., 2011; Skokanová et al., 2016). Crop production was also affected, with cropland organic carbon input maintaining increasing trend after1990 and with substantial increase in 2003-2013.

This is explained by higher production of richer crops and the slight increase in stabled animals supplying more farmyard manure to the croplands. The major effect, however, was due to the altered percentages of main crops; the shift from fodder and potato production to the biomass-rich rapeseed in North-eastern Slovakia (Tarasovičová et al., 2013).

The simulations of balanced plant residue input at equilibrium which resulted in $10 \%$ increase in average SOC stock in 1970-2013 identifies possible climate impact on SOC stock 
dynamics. There was slight $1.5 \%$ increase in mean annual temperatures, but no change in average rainfall in the pilot area (data not shown). This resulted in less soil humidity and also likely promoted greater SOC accumulation.

\section{Conclusion}

Herein, the RothC model simulated 1970-2013 SOC stock and storage temporal dynamics of the cropland and grassland topsoil in the Ondavská Vrchovina highland region. The inputs for the model were organised in a $1 \times 1 \mathrm{~km}$ spatial resolution grid and comprised nationalscale soil and weather data and the historical record of this area's land cover and land use changes.

Between 1970 and 2013, the study area was subject to major land cover and land use change, mainly because of cropland and grassland inter-conversions and the initial $61 \%$ cropland in 1970 was reduced to $45 \%$ in 2013 . The average SOC stock in 0.3 -m deep topsoil increased from 38.4 to $49.2 \mathrm{tha}^{-1}$ during that period, and the average values were $47.6 \mathrm{t} \mathrm{ha}^{-1}$ in croplands and $49.4 \mathrm{t} \mathrm{ha}^{-1}$ in grasslands. The RothC topsoil SOC stock simulated values were within the range of 1993-2013 SOC measurements.

In conclusion, the total Ondavská Vrchovina highland regional SOC storage was $4.21 \mathrm{Mt}$ in 1970 and $5.16 \mathrm{Mt}$ in 2013. This 22\% estimated gain documents the importance of land cover conversions and also the impact of organic carbon inputs to the soil from cropland and grassland management regimes. These land cover changes and soil organic carbon inputs are, therefore, most important in determining the regional SOC stock balance and estimates of total regional SOC storage. Finally, they also establish that precise reconstruction of land cover and land use dynamics is an essential prerequisite in regional SOC storage inventories where current SOC data is unavailable and contemporary regional SOC stock and storage must be accurately estimated from historical soil data.

Acknowledgements

This research was supported by the Slovak Research and Development Agency under the contract No. APVV14-0087.

\section{References}

Alvaro-Fuentes, J., Easter, M., Cantero-Martinez, C. \& Paustian K. (2011). Modelling soil organic carbon stocks and their changes in the northeast of Spain. Eur. J. Soil Sci., 62, 685-695. DOI: 10.1111/j.1365-2389.2011.01390.x.

Balkovič J., Skalský, R. \& Nováková M. (2010). Spatial model of sand and clay distribution in the topsoil of agricultural land of Slovakia. In R. Bujnovský (Ed.), Vedecké práce VÚPOP 32 (pp. 5-13). Bratislava: VÚPaOP.

Banwart, S.A., Black, H., Cai, Z., Gicheru, P.T., Joosten, H., Victoria, R.L., Milne, E., Noellemeyer, E. \& Pascual U. (2015). The global challenge for soil carbon. In S.A. Banwart, C. Noellemeyer C. \& E. Milne (Eds.), Soil carbon. Science, management and policy for multiple benefits (pp. 1-9). Oxfordshire: CABI.

Barančíková, G., Halás, J., Gutteková, M., Makovníková, J., Nováková, M., Skalský, R. \& Tarasovičová Z. (2010). Application of RothC model to predict soil organic carbon stock on agricultural soils of Slovakia. Soil and Water Research, 5, 1-9. DOI: 10.17221/23/2009-SWR.

Barančíková, G., Makovníková, J., Skalský, R., Tarasovičová, Z., Nováková, M., Halas, J., Gutteková, M. \& Koco Š. (2012). Simulation of soil organic carbon changes in Slovak arable land and their environmental aspects. Soil and Water Research, 7, 45-51. DOI: 10.17221/38/2011-SWR. 
Barančíková, G., Makovníková, J., Skalský, R., Tarasovičová, Z., Nováková, M., Halas, J., Koco, Š. \& Gutteková M. (2013). Changes in organic carbon pool in agricultural soils and its different development in individual agro-climatic regions of Slovakia. Agriculture (Pol'nhospodárstvo), 59, 9-20. DOI: 10.2478/agri-2013-0002.

Barančíková, G., Skalský, R., Koco, Š., Halas, J., Tarasovičová, Z. \& Nováková M. (2014). Farm-level modelling of soil organic carbon sequestration under climate and land use change. In G. Halldórsson, F. Bampa, A.B. Thorsteinsdóttir, B.D. Sigurdsson, L. Montanarella \& A. Arnalds (Eds.), Soil carbon sequestration for climate food security and ecosystem services (pp. 100-106). Proceedings of the International Conference 27-29 May 2013, Reykjavík, Iceland. JRC Scientific and Policy Reports. European Union JRC 88412.

Bielek P., Čurlík P., Fulajtár E., Houšková B., Ilavská B. \& Kobza J. (2005). Soil survey and managing of soil data in Slovakia. In R.J.A. Jones, B. Houšková, P. Bullock \& L. Montanarella (Eds.), Soil resources of Europe (pp. 317-329). European Soil Bureau Research Report No. 9.

Bielek, P. \& Jurčová O. (2010). Methodology of soil organic matter balance and determination the need for organic fertilization of agricultural soils (in Slovak). Bratislava: VÚPaOP.

Blažík, T., Faltan, V., Tarasovičová, Z. \& Saksa M. (2011). Land use changes in chosen districts of various productive agricultural regions in the context of transformational process. Geografický Časopis, 63, 301-323.

Campbell, E. \& Paustian K. (2015). Current developments in soil organic matter modelling and the expansion of model applications: a review. Environmental Research Letters, 10, 123004. DOI: 10.1088/17489326/10/12/123004.

Capriel, P. (2013). Trends in organic carbon and nitrogen contents in agricultural soils in Bavaria (south Germany) between 1986 and 2007. Eur. J. Soil Sci., 64, 445-454. DOI: 10.1111/ejss.12054.

Coleman, K. \& Jenkinson D.S. (2014). ROTHC-26.3 A model for the turnover of carbon in soil. Model description and windows users guide. Harpenden Herts: Rothamsted Research. https://www.rothamsted.ac.uk/sites/ default/files/RothC_guide_DOS.pdf

Falloon, P.D., Smith, P., Smith, J.U., Szabo, J., Coleman, K. \& Marshall S. (1998). Regional estimates of carbon sequestration potential: linking the Rothamsted Carbon Model to GIS databases. Biol. Fertil. Soils, 27, 236-241. DOI: 10.1007/s003740050426.

Falloon, P. \& Smith P. (2012). Modelling soil carbon dynamics. In W.L. Kutsch, M. Bahn \& A. Heinemeyer (Eds.), Soil carbon dynamics: An integrated methodology (pp. 221-244). Cambridge: Cambridge University Press.

Fazekašová, D., Boltižiar, M., Bobul'ská, L., Kotorová, D., Hecl, J. \& Krnáčová Z. (2013). Development of soil parameters and changing landscape structure in conditions of cold mountain climate (case study Liptovská Teplička). Ekológia (Bratislava), 32, 197-210. DOI: 10.2478/eko-2013-0017.

Frank, S., Schmid, E., Havlik, P., Schneider, U., Boettcher, H., Balkovič, J. \& Obersteiner M. (2015). The dynamic soil organic carbon mitigation potential of European cropland. Global Environmental Change, 35, 269-278. DOI: 10.1016/j.gloenvcha.2015.08.004.

Gottschalk, P., Smith, J.U., Wattenbach, M., Bellarby, J., Stehfest, E., Arnell, N., Osborn, T.J., Jones, C. \& Smith P. (2012). How will organic carbon stocks in mineral soils evolve under future climate? Global projections using RothC for a range of climate change scenarios. Biogeosciences, 9, 3151-3171. DOI: 10.5194/bg-93151-2012.

Guo, L.B. \& Gifford R.M. (2002). Soil carbon stocks and land use change: a meta analysis. Global Change Biology, 8, 345-360. DOI: 10.1046/j.1354-1013.2002.00486.x.

Hraško, J. \& Bedrna Z. (1970). Soil mapping on the territory of Slovakia. In J. Hraško (Ed.), Vedecké práce výskumného ústavu pôdoznalectva a výživy rastlín v Bratislave č. 4 (pp. 13-19). Bratislava: Príroda.

Janzen, H.H. (2006). The soil carbon dilemma: Shall we hoard it or use it?. Soil Biol. Biochem., 38, 419-424. DOI: $10.1016 /$ j.soilbio.2005.10.008.

Kaczynski, R., Siebielec, G., Hanegraaf, M.C. \& Korevaar H. (2017). Modelling soil carbon trends for agriculture development scenarios at regional level. Geoderma, 286, 104-115. DOI: 10.1016/j.geoderma.2016.10.026.

Kobza, J. (2015). Permanent soil monitoring system as a basic tool for protection of soils and sustainable land use in Slovakia. Earth and Environmental Science, 25, 012011. DOI: 10.1088/1755-1315/25/1/012011.

Lehtinen, T., Schlatter, N., Baumgarten, A., Bechini, L., Kruger, J., Grignani, C., Zavattaro, L., Costamegna, C. \& Spiegel H. (2014). Effect of crop residua incorporation on soil organic carbon and greenhouse gas emissions in European agricultural soils. Soil Use Manag., 30, 524-538. DOI: 10.1111/sum.12151.

Leifeld, J., Reiser, R. \& Oberholzer H.R. (2009). Consequences of conventional versus organic farming on soil carbon: results from a 27 year field experiment. Agron. J., 101, 1204-1218. DOI: 10.2134/agronj2009.0002. 
Linkeš, V., Gromová, A., Lupták, D., Pestún, V. \& Poliak P. (1988). Informačný systém o pôde. Bratislava: Príroda.

Ludwig, B., Schultz, E., Rethemeyer, J., Merbach, I. \& Flessa H. (2007). Predictive modeling of C dynamics in the long-term fertilization experiment at Bad Lauchstadt with the Rothamsted carbon model. Eur. J. Soil Sci., 58, 1155-1163. DOI: 10.1111/j.1365-2389.2007.00907.x.

Ma, K., Liu, J., Balkovič, J., Skalský, R., Azevedo, L. \& Kraxner F. (2016). Changes in soil organic carbon stocks of wetlands on China's Zoige plateau from 1980 to 2010. Ecol. Model., 327, 18-28. DOI: 10.1016/j.ecolmodel.2016.01.009.

Makovníková, J. \& Širáň M. (2011). Modelovanie rovnovážnej objemovej hmotnosti pôdy. Bratislava: VÚPaOP.

Masný, M., Weis, K. \& Boltižiar M. (2017). Agricultural abandonment in chosen terrain context - case study from the Polana UNESCO Biosphere Reserve (Central Slovakia). Ekológia (Bratislava), 36, 339-351. DOI: 10.1515/ eko-2017-0027.

Minasny, B., McBrandan, A.B., Malone, B.P., Lacoste, M. \& Walter C. (2014). Quantitatively predicting soil carbon across landscapes. In A. Hartemink \& K. McSweeney (Eds.), Soil carbon (pp. 45-57). Heidelberg: Springer Cham. DOI: 10.1007/978-3-319-04084-4.

Mojses, M. \& Petrovič F. (2013). Land use changes of historical structures in the agricultural landscape at the local level - Hriňová case study. Ekológia (Bratislava), 32, 1-12. DOI: 10.2478/eko-2013-0001.

Němeček, J., Damaška, J., Hraško, J., Bedrna, Z., Zuska, V., Tomášek, M. \& Kalenda M. (1967). Průzkum zemědělských půd ČSSR - souborná metodika (1. díl). Praha: Ministerstvo zemědělství a výživy.

Schulp, C.J.E. \& Verbung P.H. (2009). Effect of land use history and site factors on spatial variation of soil organic carbon across a physiographic region. Agric. Ecosyst. Environ., 133, 86-97. DOI: 10.1016/j.agee.2009.05.005.

Skokanová, H., Faltan, V. \& Havlíček V. (2016). Driving forces of main landscape change processes from past 200 years in Central Europe - differences between old democratic and post-socialist countries. Ekológia (Bratislava), 35, 50-65. DOI: 10.1515/eko-2016-0004.

Smith, J., Smith, P., Wattenbach, M., Zaehle, S., Hiederer, R., Jones, R.J.A., Montanarella, L., Rounsevell, M.D.A., Reginster, I. \& Ewert F. (2005). Projected changes in mineral soil carbon of European croplands and grasslands, 1990-2080. Global Change Biology, 11, 2141-2152. DOI: 10.1111/j.1365-2486.2005.001075.x.

Tarasovičová, Z., Saksa, M., Blažík, T. \& Faltan V. (2013). Changes in agricultural land use in the context of ongoing transformational processes in Slovakia. Agriculture (Polnohospodárstvo), 59, 49-64. DOI: 10.2478/agri-20130005 .

van Wesemael, B., Paustian, K., Meersmans, J., Goidts, E., Barančíková, G. \& Easter M. (2010). Agricultural management explains historic changes in regional soil carbon stocks. PNAS, 107(33), 14926-14930. DOI: 10.1073/ pnas.1002592107.

Vopravil, J., Podrázský, V., Khel, T., Holubík, O. \& Vacek S. (2014). Effect of afforestation of agricultural soils and tree species composition on soil physical characteristics changes. Ekológia (Bratislava), 33, 67-80. DOI: 10.2478/ eko-2014-0008.

Wang, G., Luo, Z., Han, P., Chen, H. \& Xu J. (2016). Critical carbon input to maintain current soil organic carbon stocks in global wheat systems. Scientific Reports, 6. DOI: 10.1038/srep19327.

Wang, J., Lu, S., Xu, M., Zhu, P., Huang, S., Zhang, W., Peng, C., Chen, X. \& Wu L. (2013). Soil organic carbon sequestration under different fertilizer regimes in north and northeast China: RothC simulation. Soil Use Manag., 29, 182-190. DOI: 10.1111/sum.12032. 